УДК 338.48

\title{
ПРОБЛЕМА ЗАХИСТУ БРЕНДУ ЯК ОБ'ЄКТУ ІНТЕЛЕКТУАЛЬНОЇ ВЛАСНОСТІ У ТУРИЗМІ
}

\section{THE PROBLEM OF BRAND PROTECTION AS AN OBJECT OF INTELLECTUAL PROPERTY IN TOURISM}

\author{
Дехтяр Надія Анатоліївна \\ кандидат економічних наук, доцент, \\ Харківський національний економічний університет імені Семена Кузнеця \\ ORCID: https://orcid.org/0000-0001-7932-8620
}

Dekhtyar Nadiya

Simon Kuznets Kharkiv National University of Economics

\begin{abstract}
Стаття присвячена питанням захисту бренду туристичного продукту під час виходу національних підприємств на зовнішні ринки; аналізується процедура реєстрації торгової марки на території єС; визначено особливості елементів торгової марки для туристичної продукції та вимоги споживачів, що висуваються до текстового та графрічного представлення; наведено приклади судових позовів резидентів ЄС щодо порушення прав інтелектуальної власності та випадків відмови у реєстрації торгової марки; з використанням бази даних Відомства з інтелектуальної власності ЄС проаналізовано склад та структуру виданих сертисрікатів, які містять найбільш поширені семантичні одиниці; підкреслена необхідність попереднього визначення інфрормаційного поля унікальності бренду перед початком процедури фрормальної реєстрації.
\end{abstract}

Ключові слова: торгова марка, право інтелектуальної власності, туристичні бренди.

Статья посвящена вопросам защиты бренда туристического продукта при выходе национальных предприятий на внешние рынки; анализируется про-цедура регистрации торговой марки на территории ЕС; определены особен-ности элементов торговой марки для туристической продукции и требования потребителей, предъявляемые к текстовому и грасрическому представлению; приведены примеры судебных исков резидентов ЕС о нарушении прав интеллектуальной собственности и случаев отказа в регистрации торговой марки; с использованием базы данных Ведомства по интеллектуальной собственности ЕС проанализирован состав и структура выданных сертисрикатов, содержащих наиболее распространенные семантические единицы; подчеркнута необходимость предварительного определения инорормационного поля уникальности бренда перед началом процедуры фрормальной регистрации.

Ключевые слова: торговая марка, право интеллектуальной собственности, туристические бренды.

The article is devoted to the issues of protection of the tourist product brand, which should be resolved by national enterprises when entering foreign markets. The contradictions are highlighted that arise in the case of accidental identity of brand elements the of companies resident in different countries. The aim of the article is to develop a methodical approach to the choice of strategy for the promotion of tourism services in foreign markets based on the analysis of formal procedures for ensuring intellectual property rights. The main task is to develop recommendations for Ukrainian travel companies that plan to export their own brand and expand the range of proposals, based on the analysis of the process of trade mark registration and the scope of existing brands in the field of tourism and hospitality in the EU. The study analyses the procedure of trade mark registration in the EU; identifies the peculiarities of brand elements for tourist products and consumer requirements for textual and graphical representation (it is noted that for most goods and services the name can be chosen without descriptive reference, i.e. accurate semantic identification of the product, and in the field of leisure services, a certain set of keywords is commonly used, which significantly narrows the alternatives for presenting a product or a company); examples of lawsuits filed by EU residents for infringement of intellectual property rights and cases of refusal to register a trade mark, the reason for which is the existence of supranational jurisdiction. Using the database of the EU Intellectual Property Office, the composition and structure of issued certificates containing the most common semantic units were analysed (the words "tourism", "travel", "resort", "recreation", "hotel" and "hospitality" were chosen as an example); the keywords "hotel" and "travel" were found to be the most commonly used in the sample, while "tourism" and "hospitality" accounted for less registered trade marks. The register includes, in addition to EU countries, other world states, but their range is still narrow. The need to pre-determine the information field of brand uniqueness before the formal registration procedure is emphasised, namely, the domain names semantic analysis is recommended, both in the product type and geographical scope.

Keywords: trade mark, intellectual property rights, travel brands. 
Постановка проблеми. Вихід національних туристичних підприємств на закордонні ринки супроводжується додатковими витратами на заходи із ознайомлення потенційних споживачів із новою для них торговою маркою та створенням позитивного іміджу із урахуванням суспільних традицій, норм, звичаїв, способу життя та обмежень локального ділового середовища. Якщо ідея, концепція продукту та у цілому місія компанії не суперечать настроям місцевого населення, процес введення іноземної пропозиції $€$ подекуди технічним, із застосуванням тих прийомів комплексу маркетингу, які є для підприємства-імпортера добре відомими та напрацьованими й відповідають досвіду роботи у даній галузі. Розпізнаваність бренду компанії та продукту досягається відносно легко, адже у арсеналі сучасних виробників є майже безкоштовний ресурс онлайн медіа (сьогодні найвживанішими вважаються соціальні мережі, блоги та мессенджери), за допомогою яких можна привернути увагу до продукту. Формування лояльності та пошук прихильників - дещо складніший процес, але сутність маркетингових технологій, які при цьому використовуються, здебільшого відповідає і внутрішньому ринку, змінюється лише змістовне наповнення. Проблеми починають виникати тоді, коли добре відомий та прибутковий бренд з певних причин неможливо вивести на цільовий ринок, і потрібно «на льоту» переорієнтовувати стратегію просування продукту. Однією із причин такої вкрай несприятливої для експортера ситуації стає відмова у реєстрації пропонованої торгової марки чи вимоги щодо ії̈ суттєвої зміни, і використати переваги відомого бренду стає неможливим. Тому актуальним $€$ питання нормативного забезпечення захисту прав власності на торгові марки (які у цьому випадку ототожнюються 3 брендами) та розуміння вимог національних ринків щодо їх характеристик. Туристичні послуги володіють додатковими, притаманними лише галузі рекреації і дозвілля, ознаками, що зумовлює деякі обмеження у використанні загальноприйнятих процедур міжнародного приватного права.

Аналіз останніх досліджень і публікацій. Процедури реєстрації прав інтелектуальної власності $€$ достатньо формалізованими, тому наукові публікації даної тематики намагаються дослідити ті проблемні області та суперечності (у законодавстві, державному управлінні, процесі інституційних утворень), які $€$ обов'язковим підґрунтям забезпечення цих формальних процедур. Як приклад,
С. Мельниченко, Н. Ведмідь та О. Авдан [1] звертають увагу на підвищену складність процесу реєстрації в Україні, що може стримувати розвиток підприємництва; О.Ю. Боєнко [2] детально аналізує питання створення та захисту національних брендів. І.А. Романюк [3] наголошує на необхідності забезпечення захисту інфрормаційного середовища малих туристичних підприємств. С.М. Ілляшенко, О.М. Проскурня та М.О. Попов [4] розглядають об'єкти IB як новий тип товару, який стане головним у інформаційному суспільстві. Туристична галузь в Україні $є$ інтелектуально насиченою, тому що попит перш за все існує на тури із поєднанням пізнання, відпочинку та самоосвіти. Взагалі, якщо публікацій із загальних питань інтелектуальної власності чимало, то галузь туризму $є$ ще недостатньо висвітленою, дослідженням інколи не вистачає системності. Українські вчені більше приділяють увагу аспектам фрормування і оцінки інноваційного потенціалу, інтелектуального капіталу і суміжним темам у сорері туристичної діяльності, аніж питанням захисту прав інтелектуальної власності чи практичним завданням процедурного змісту.

Виділення невирішених раніше частин загальної проблеми. Різноманітні аспекти теоретичних досліджень та практичної реалізації норматив-них процедур реєстрації та використання торгових марок у сорері міжнарод-ної торгівлі послугами є достатньо висвітленими у науковій літературі, проте бракує праць, які б роз'яснювали status quo та надавали рекомендації стосовно конкретних регіональних ринків, а також пропонували методики визначення оптимального способу поведінки підприємства під час проходження фрормальних процедур, адже вони в основному уніфріковані для країн із активною присутністю на глобальному ринку, а-от зміст деяких етапів може суттєво відрізнятися в залежності від ділової практики, прийнятої у країні.

Формулювання цілей статті (постановка завдання). Метою статті $€$ розроблення методичного підходу до вибору стратегії просування туристичної послуги на закордонних ринках на основі аналізу срормальних процедур забезпечення прав інтелектуальної власності. Основне завдання полягає у розробленні рекомендацій для туристичних компаній України, які планують виводити власний бренд на експорт та розширювати номенклатуру пропозиції, на прикладі аналізу процесу реєстрації торгової марки та наявних брендів у галузі туризму та гостинності у країнах $€ C$. 
Виклад основного матеріалу дослідження. Захист прав інтелектуальної власності у зовнішньоекономічних відносинах, як і будь-якій іншій законодавчій царині, де зустрічаються інтереси представників різних держав, ускладнюється застосуванням санкцій (тобто притягненням порушників до відповідальності) та забезпеченням рівного доступу до інфрормації усіх учасників ділового співробітництва (останнє значно знижує рівень порушень, адже керівництво і персонал компаній, які фрізично знаходяться у іншій країні, не володіють всіма нюансами локальних ринків і не в змозі скласти комплексну картину тенденцій, що є у даний період визначальними). Незважаючи на достатньо тривалий шлях інтеграційних процесів, який пройшла Україна шляху співробітництва з Європейським Союзом, залишаються відмінними багато законодавчих положень та практик ведення бізнесу. У рамках пропонованого дослідження зупинимося детально на питанні використання торгової марки як частини стратегії брендингу та/або представлення компанії-експортера туристичних послуг.

Як відомо, назва продукту є ключовим елементом його запам'ятовування та вироблення асоціацій у свідомості споживача. В залежності від емоційного забарвлення та ініційованого поштовху до очікуваних дій, створюються інші складові бренду - логотип, слоган (який доповнює та роз'яснює або назву індивідуального продуктового бренду, або місію підприємства, якщо мова йде про бренд виробника / постачальника послуг), корпоративна культура тощо. I якщо для більшості товарів і послуг назва може обиратися без так званої описової прив'язки (точної семантичної ідентифрікації продукту), то споживачі послуг дозвілля звикли до наявності певного набору ключових слів. Наприклад, виробники автотранспортних засобів не повинні включати слово "автомобіль", "автобус" чи його частину (корінь) у назву торгової марки (бренду) засобів пересування. Навпаки, назва походить із зовсім іншого лексичного ряду та викликає асоціації $з$ ситуаціями, де краще використовувати автомобіль саме цієї марки, чи способом самовираження, прихильності до якоїсь ідеї, ототожнення себе із окремим суспільним прошарком чи субкультурою. Бренд "Tesla" acoціюється із інноваційністю та збереженням довкілля, "Audi" - 3 престижністю та успіхом, і т.д. Але компанії-перевізники дуже часто використовують слова, що характеризують транспортний засіб, у власних назвах - зга- даємо "British Airways", "Air France", "China Railway", українські бренди "Автолюкс", "МАУ", "Укрзалізниця". Туристичні оператори та посередники-агенти відповідно до усталеного ділового звичаю включають до назви слова "туризм", "туристичний", "подорож", якщо вони спеціалізуються на якомусь одному виду відпочинку - додають характерні лексичні одиниці. Заклади розміщування використовують відповідно слова "готель", "мотель", "хостел" та інші в залежності від типу. Типова структура назви складається із слова-ключової ознаки послуги (туризм, подорожі, перевезення, розміщування), що є спільними для підприємств цього виду діяльності, та іншого слова чи фррази, що повинне відрізняти дане підприємство від конкурентів. Власне, воно і визначає унікальність, розпізнаваність бренду. Цікаво, що на заклади харчування, які $є$ невід'ємною складовою рекреаційної інфрраструктури, це правило не поширюється. Звичайно, є виключення - відомі компанії із унікальною нейтральною назвою, але для новостворених підприємств, що ще не набули стійких асоціацій із типом продукту у свідомості споживачів, така нейтральна назва потребуватиме додаткових зусиль для запам'ятовування. Зараз "Black Tomato" (https://www.blacktomato.com, у пер. 3 англ. "чорний помідор") є відомим туристичним оператором із штаб-квартирою у Лондоні, але якщо про це не знати, із яким типом продукції можна було б співвіднести цю назву? Тому багато туристичних компаній тяжіє до традиційної структури назви бренду. Із логотипами спостерігається подібна ситуація - вони часто складаються із зображень предметів або природних об'єктів, з якими у цільового споживача асоціюється відпочинок. Абстрактні, лексично та графрічно нейтральні логотипи теж зустрічаються, але часто вони використовуються разом із слоганом чи текстовим повідомленням, покликаним полегшити споживачу процес сприйняття та запам'ятовування.

Тож у чому полягає проблема? Торгова марка (у текстовому чи візуальному вигляді) повинна, по-перше, бути унікальною, відрізнятися від вже зареєстрованих брендів; по-друге, бути індивідуальною, не містити загальновживаних лексичних одиниць із широкою сорерою застосування; по-третє, якомога краще ідентиорікувати продукт. Правда, із останнім можна посперечатися, ця вимога начебто суперечить першим двом: як "підказати", чим займається компанія чи що означає даний товар, не використовуючи спеціальні терміни, перелік яких 
обмежений? Найперші товарні знаки, що були зареєстровані у країнах ЄС, містили словосполучення (зі словами "туризм", "подорож" чи "відпочинок"), але зараз подібні реєстраційні заяви відхиляють, користуючись вимогою щодо заборони подібності назви до вже існуючої. Звісно, нечесні дії "сірих" виробників, які підроблювали товар відомих брендів та продавали їх під назвами, у яких видаляли чи замінювали одну-дві літери, можна припинити тільки таким способом (вірніше, довести їх нелігітимність), але як встановити подібність назви готельних мереж, що містять словосполучення "Hotel Group"? Логічно, тільки за тим словом, що відрізняється, а вказана стандартна фрраза просто не береться до уваги. Але чому такий підхід часто не спрацьовує у розгляді заяв на реєстрацію торгової марки чи судових позовів інших учасників туристичного ринку? Показовим $€$ відхилення заяви Відомством 3 інтелектуальної власності ЄC (European Union Intellectual Property Office - EUIPO) щодо реєстрації TM "Smart Travel" (документ № 20170125_015767833 у реєстрі EUIPO). Причиною відмови стало те, що пропонована назва носить описовий характер та не задовольняє критерію відмінності. Також зазначалося, що "неологізм 'smart travel' (з англ. "кмітлива подорож"), будучи досить розмитим ..., не використовується споживачами чи продавцями для опису основних характеристик товару". Якщо із першою тезою ми цілковито погоджуємося, то друга може бути спростована, адже слово "smart" міцно увійшло до ознак інноваційних, незвичайних послуг. Тим більше, ТМ "Smart Traveller" (з англ. "кмітливий подорожуючий") була зареєстрована 07.08.2006 р. (реєстраційний номер 004633665, власник Telekom Deutschland $\mathrm{GmbH}$ ). Відомство також відмовило у реєстрації ТМ "fairbnb.coop community powered tourism" (заява № 002966059), аргументуючи тим, що заявлена назва сильно подібна до TM "Air BNB" (крім того, у період відкритого розгляду юридичний представник останньої подав зустрічне зауваження до офрісу Відомства). 3 одної сторони, у 35-знаковій фрразі ідентифрікатор "airbnb" займає усього 17\% і ключовим словом тут може бути "fair" (англ. "справедливий"), а не "air" (англ. "повітря"), 3 іншої - портал із бронювання житла "airbnb" $€$ міжнародним брендом, надзвичайно популярним серед туристів. 3 першого погляду у адресі сайту fairbnb.coop навіть складно виділити додаткову літеру "f", що надає іншого лексичного значення ключовому слову.
У процедурі реєстрації іноземних торгових марок додаткове джерело конорліктів - це протистояння між національними компаніями 3 одної чи різних держав, які вже мають власні бренди і помічають, що третя сторона хоче використати подібні назву чи логотип. Зауважимо, що подібна ситуація стала можливою у $€ C$ як наддержавному об'єднанні із спільними інститутами та розмежуванням правового поля на сфреру національної відповідальності та юрисдикції ЄС як інтеграційної одиниці вищого рівня. Справа проти заявника з Болгарії (який подав заяву на реєстрацію логотипу із певним словосполученням) та представництва EUIPO (логотип був зареєстрований) (у реєстрі EUR-Lex документ № 62014TJ0567, справа № Т-567/14) була ініційована іншою болгарською компанією на підставі звинувачення EUIPO у позитивному рішенні щодо дозволу на використання незареєстрованої на спільній території ЄС ії̈ національної торгової марки, яка тим не менш була у вжитку протягом тривалого часу. Зокрема, бренд використовувався організатором туристичних перевезень в Угорщині, Польщі, Словаччині та Чехії; окремо ТМ не була зареєстрована, але перевізник отримав транспортну ліцензію державного зразка, де була вказана спірна назва. Оскільки у реєстрі EUIPO така назва не фрігурувала, зустрічне зауваження цієї компанії було відхилено. Логіка, якою користувалися фрахівці Відомства, була наступною: а) існує фрізична чи юридична особа, яка хоче зареєструвати торгову марку; б) пропонована назва/логотип відповідає вимогам щодо унікальності за результатами семантичного / графрічного аналізу; в) вона не значиться у базі даних Відомства, тобто на території ЄС як єдиного інтеграційного об'єднання поки немає інших власників на заявлений текст / логотип і вона не є подібною до наявних у базі записів; г) отже, таку марку можна дозволити до використання у всіх країнах $€ C$, а якщо подібна ТМ існує в іншій країні, входить ця держава у склад ЄС чи ні, несуттєво - вона ж формально не внесена до реєстру! Колізія трапилася тому, що реєстрація TM у EUIPO для використання на всій території $€ С$ не $€$ обов'язковою, якщо власник цієї національної ТМ (вона може бути офріційно зареєстрована у одній з країн-членів, а може й використовуватися просто як елемент ідентисрікації бренду без захисту прав інтелектуальної власності) працює виключно на внутрішньому ринку. Якщо хтось інший вирішить використати "незайняте" словосполучення, це його право. Національні компанії можуть від- 
стежувати публікації EUIPO із поданими пропозиціями, але довести, що заявники порушують їх право власності, для малих та середніх невідомих компаній вкрай складно. 3 іншої сторони, вони як підприємства, зареєстровані на території ЄС, мають право скористатися ресурсами офріційних інститутів, у тому числі забезпечити право власності. Якщо 3 якоїсь причини підприємство не залишає за собою виключне право на використання певного логотипу, значить, не заперечує проти його використання кимось іншим. Справа, про яку йшла мова вище, була вирішена на користь позивача і може слугувати прецедентом, але правова система $€ \subset$ не надає прецедентам виключну значущість, як класична англо-саксонська, тому з іншою компанією може трапитися протилежна ситуація. Такий хід подій варто було б передбачити і запропонувати усім резидентам $€ С$ зареєструвати власні бренди у єдиній базі. Знову-ж таки, виявилися б місцеві продукти виключно для внутрішнього споживання із однаковими чи подібними назвами у різних країнах, але можна було б додати до пакету документів згоду власника на використання подібних елементів у інших країнах (там, де він не збирається провадити діяльність), чи включити до назви/логотипу ознаки національної належності.

На світовому ринку, де взаємодія між учасниками ґрунтується на віднесенні суб'єктів економічної діяльності виключно до двох рівнів - національного (внутрішні справи кожної держави на власній території, яка вона вирішує самостійно, відповідно до свого законодавства) та міжнародного, де представники з різних країн взаємодіють як рівні самостійні одиниці та повинні визначити, яких унісрікованих правил вони дотримуватимуться (що і складає систему міжнародного приватного права). Наприклад, туристичний оператор з України працює виключно у межах країни і має зареєстровану уповноваженим органом державної влади з інтелектуальної власності торгову марку. Тоді усі інші туроператори-резиденти України чи іноземні компанії не мають права ії використовувати. Але якщо якийсь туристичний оператор 3, припустимо, Канади випадково зареєструє там таку ж саму назву, він так само вільно використовуватиме іiї на своїй території. А от коли наша українська компанія виходитиме на ринок Канади, їй буде заборонено використовувати легітимний в Україні бренд, бо він співпадає із місцевим, і потрібно буде саме для територій під юрисдикцією Канади реєструвати нову торгову марку. Така проблема існує і з патентами, i іншими фрор- мами захисту об'єктів інтелектуальної власності. Не існує єдиної процедури щодо міжнародного визнання брендів, та й подібні задачі виникають в основному у ТНК, у яких достатньо авторитету для вирішення спірних питань.

Втім, із поширенням Інтернет-торгівлі та онлайн маркетингу (зокрема просування продукції або бренду шляхом створення сайтів-візитівок чи сторінок у соціальних мережах) проблема міжнародної ідентисрікації постає ще нагальніше. Якщо власник компанії вирішує заощадити кошти і не використовувати домени першого рівня (наприклад, brandname.com), а зупиняється на варіанті доменних імен другого-третього рівнів (brandname.com.ua чи brandname.kharkiv.com.ua), у разі використання поширених лексичних одиниць у якості brandname (причому ця TM офріційно зареєстрована у країні, резидентом якої $€$ компанія) цілком ймовірна ситуація, що будуть зареєстровані майже однакові, 3 точки зору користувача, назви, які відрізнятимуться тільки доменними зонами. Компанії 3 різних країн і не планують експорт, власний сайт чи брендова сторінка у соцмережах (де головним критерієм $€$ неспівпадання логіну, а наявність реєстрації ТМ може взагалі не перевірятися, якщо сторінка приватна і її веде працівник підприємства суто для спілкування 3 невеликою групою споживачів) їм потрібні виключно для охоплення внутрішнього ринку, але для всесвітньої мережі обрані назви є рівними у статусі, за певних налаштувань пошукової системи будуть показані усі сторінки із brandname, навіть ті, про які користувач не здогадувався. Тому для запобігання ймовірних помилкових результатів запиту варто перевірити всесвітню мережу на наявність тотожних доменних імен. У соціальних мережах і блогах забезпечити унікальність ще складніше, адже існує безліч приватних сторінок, у назві яких фрігурують різноманітні комбінації ключових слів і подекуди відсутній механізм захисту власника бренду (на відміну від нової політики ICANN), тому єдине, що лишається компанії - придумати новий варіант назви. 3 технічних причин, серед яких складність обробки та збереження надвеликих масивів даних, на сьогодні більший порядок існує серед регіональних реєстраторів, і підприємства, які працюють виключно в одному географрічному регіоні, не звертаються за консультацією до представників з іншої частини світу.

Якщо туристична компанія-резидент України вирішить зареєструвати бренд у EUIPO, перше, що необхідно виявити - це усталені 
звичаї та прийнятні змістовні форми. Недостатньо просто перевірити бажану назву/логотип на предмет відсутності серед зареєстрованих ТМ чи заяв, що знаходяться у процесі розгляду. Варто зрозуміти, за яким принципом краще побудувати композицію графрічного зображення чи лексичну одиницю для назви, хай вона і буде трохи відрізнятися від українського варіанту. Навряд споживачі із різних країн порівнюватимуть обидва варіанти та звертатимуть увагу на незначні відмінності. Туристи з України (повертаючись до прикладу, наведеного вище) звертатимуться до офісів туроператора, розташованих в Україні, а не в Канаді, і навпаки, громадяни Канади, плануючи подорож до України, купуватимуть тур у локальному представництві, і воно ж буде завершувати документарний супровід. У табл. 1 представлено аналіз діючих на даний час прав на торгові марки на усій території ЄС.

Як видно 3 таблиці, найуживанішими у виборці є ключові слова "hotel" та "travel", а на частку "tourism" та "hospitality" припадає набагато менше зареєстрованих ТМ. У реєстрі представлені, окрім країн $€ C$, інші держави 3 усього світу, але їх перелік незначний. В основному сорера діяльності EUIPO зосереджена у країнах Європи, але зустрічаються й спільні права власності представників із різних країн. Лише один бренд, який ввійшов у досліджувану вибірку - "L LEOBEDS HOTELS \& RESORTS" (номер сертифрікату 018079617 від 04.10.2019р.) - має власника-громадянина України (але офріційний представник знаходиться в Іспанії). Скоріше за все, у результаті занепаду туристичної галузі у 2020 р. власник ТМ вирішив не проваджувати комерційну діяльність, адже інфрормації про даний бренд у мережі Інтернет немає. Усього у реєстрі EUIPO нараховується 582 власники TM - громадяни та юридичні особи-резиденти України, серед них велику частку займають представники крупних медіа та орієнтованих на експорт промислових виробників.

3-поміж суб'єктів туристичної діяльностірезидентів України $€$ достатньо таких, що планують починати або продовжувати діяльність на ринку ЄС з укладанням угод чи принаймні проводити маркетингову кампанію із залучення іноземних туристів в Україну після відкриття кордонів. Отримання сертифікату процес довготривалий, у середньому потрібно принаймні 6-8 місяців на підготовку документів та розгляд заяви. Тому українським компаніям варто було б розпочати аналіз наявних ТМ у своїй сорері діяльності, щоб у разі необ- хідності мати достатній час на ребрендинг та виявити потенційних конкурентів, які можуть відволікати частину інорормаційного простору.

Методичний підхід до стратегії просування продукції на експорт у частині здійснення срормальних процедур реєстрації прав інтелектуальної власності можна представити у вигляді послідовності дій або алгоритму, якого рекомендовано дотримуватися власникам торгових марок чи інших об'єктів:

1) визначення інфрормаційного поля, де бренд чи інший елемент повинен бути унікальним (наприклад, у полі доменних імен різних рівнів);

2) визначення правового поля уніфрікації: реєстрація виключно у межах одної країни, чи охоплення якомога ширшого географрічного діапазону;

3) обрання типу об'єкта права інтелектуальної власності (у статті йшла мова про торгові марки, але пропонований алгоритм можна застосовувати і до інших). Потрібно мати на увазі, що часто реєструються тотожні бренди, якщо вони належать до різних сорер діяльності (як-от кодів NACE);

4) аналіз вибірки 3 існуючих реєстрів та перевірка унікальності усіх елементів бренду. У разі випадкового збігу необхідно вирішити, якої поведінки у подальшому дотримуватися модифрікації складових існуючого бренду до стану, коли він ймовірно пройде перевірку на унікальність, чи повного ребрендингу послуг для ринків окремих країн.

Висновки. У ході дослідження було отримано такі результати:

туристичні компанії-резиденти України недостатньо представлені у реєстрі Відомства з інтелектуальної власності ЄC (EUIPO), що може призвести до виникнення конфрліктних ситуацій та правових спорів у разі провадження підприємницької діяльності у європейських країнах;

споживачі туристичних послуг асоціюють бренди із обмеженим набором ключових елементів (грасрічних чи лексичних), що ускладнює побудову унікального профрілю продукту та інколи призводить до суперечливих рішень реєстраторів прав інтелектуальної власності;

поки не існує дієвої системи ідентифрікації об'єктів права інтелектуальної власності на міжнародному рівні та порядку забезпечення виконання санкцій учасниками глобального ринку, але доцільно використовувати досвід $€ C$ у вирішенні спорів, що знаходилися під юрисдикцією спільноти як інтеграційного наднаціонального об'єднання. 
Таблиця 1

Ключові слова у зареєстрованих EUIPO торгових марках

\begin{tabular}{|c|c|c|c|c|c|c|c|}
\hline \multirow{2}{*}{\multicolumn{2}{|c|}{$\begin{array}{l}\text { Зведені характеристики } \\
\text { зареєстрованих ТМ }\end{array}$}} & \multicolumn{6}{|c|}{ слово у назві торгової марки } \\
\hline & & urism & travel & resort & recreation & hotel & 105 \\
\hline \multicolumn{2}{|c|}{ Загальна кількість, з них: } & 17 & & & 0 & & \\
\hline \multicolumn{2}{|c|}{ виключно текстові (word) } & & & & & & \\
\hline \multicolumn{2}{|c|}{ графрічні (figurative) } & & & & & & \\
\hline \multicolumn{2}{|c|}{ 3D зображення (3D shape) } & & & & & & \\
\hline \multicolumn{2}{|c|}{ Інша фрорма( other) } & - & - & - & & & - \\
\hline \multicolumn{8}{|c|}{$\begin{array}{c}\text { Країни, резидентами яких є власники торгових марок (кількість сертиорікатів), } \\
\text { За ключовими словами }\end{array}$} \\
\hline & \multicolumn{7}{|c|}{$\begin{array}{l}\text { Іспанія (30), Італія (17), Німеччина (14), Франція (14), Австрія (7), Сполучене Королівство } \\
\text { (7), Китай (3), Португалія (3), Фінляндія (2), Греція (2), Угорщина (2), США (2), Бельгія } \\
(1), \text { Болгарія (1), Чехія (1), Гонконг (1), Мальта (1), Нідерланди (1), Румунія (1), Словенія } \\
\text { (1), ОАЕ (1); спільна власність: Бельгія (2), Бельгія та Мальта (1), Естонія та Австрія (1), } \\
\text { країна не визначена (1) }\end{array}$} \\
\hline & \multicolumn{7}{|c|}{$\begin{array}{l}\text { Німеччина (257), Сполучене Королівство (240), Іспанія (182), США (171), Італія (106), } \\
\text { Франція (67), Нідерланди (66), Польща (43), Китай (35), Швеція (33), Австрія (32), } \\
\text { Швейцарія (31), Греція (26), Португалія (25), Румунія (15), Бельгія (14), Чехія (13), } \\
\text { Австралія (12), Ірландія (12), Канада (12), Гонконг (11), Люксембург (11), Болгарія (9), } \\
\text { Норвегія (9), Данія (8), Кіпр (7), Тайвань (7), Литва (6), Японія (6), Мексика (5), ОАЕ (5), } \\
\text { Сінгапур (5), Словаччина (5), Фінляндія (5), Віргінські Острови (Брит.) (4), Естонія (4), } \\
\text { Мальта (4), Бразилія (3), Російська Федерація (3), Угорщина (3), Багами (2), В'єтнам (2), } \\
\text { Ізраїль (2), Кайманові Острови (2), Колумбія (2), Малайзія (2), Монако (2), Туреччина (2), } \\
\text { Чилі (2), ШріЛанка (2), Андорра (1), Аргентина (1), Бермуди (1), Гернсі (1), Джерсі (1), } \\
\text { Індія (1), Катар (1), Корея Півд. (1), Кувейт (1), Кюрасао (1), Ліхтенштейн (1), Маврикій (1), } \\
\text { Панама (1), ПАР (1), Перу (1), Свазіленд (1), Сербія (1), Словенія (1), Туніс (1), Ямайка (1); } \\
\text { спільна власність: Іспанія (3), Італія (3), Німеччина (2), Сполучене Королівство (2), США } \\
\text { (2), Австралія, Швейцарія (1), Австрія (1), Гонконг (1), Іспанія, Бельгія, Ліван (1), Італія, } \\
\text { СшА (1), Кіпр, Греція (1), Нідерланди (1), Німеччина, Китай (1), Польща (1), Польща, } \\
\text { Ірландія (1), Португалія (1), Португалія, Бразилія (1), Словаччина, Чехія (1), Угорщина (1) }\end{array}$} \\
\hline & \multicolumn{7}{|c|}{$\begin{array}{l}\text { спанія (110), США (66), Німеччина (38), Італія (35), Греція (28), Сполучене Королівство } \\
\text { 28), Португалія (21), Сінгапур (20), Нідерланди (15), Франція (14), Австрія (13), Віргінські } \\
\text { строви (Брит.) (9), Панама (9), Швейцарія (9), Бельгія (7), Маврикій (6), Гонконг (5), } \\
\text { аїланд (5), Кіпр (4), Мексика (4), Туреччина (4), Хорватія (4), Японія (4), Польща (3), } \\
\text { лловаччина (3), Фінляндія (3), Чехія (3), Швеція (3), Багами (2), Болгарія (2), Індія (2), } \\
\text { оландія (2), Китай (2), Кюрасао (2), Латвія (2), Люксембург (2), Марокко (2), Румунія (2), } \\
\text {;ловенія (2), Угорщина (2), Австралія (1), Гібралтар (1), Данія (1), Естонія (1), Кайманові } \\
\text { строво (1), Канада (1), КостаРіка (1), Кувейт (1), Ліван (1), Норвегія (1), ОАЕ (1), ПАР } \\
\text { 1), СентЛюсія (1), Україна (1), Ямайка (1); спільна власність: Франція (1), Франція, } \\
\text { юксембург (1), Німеччина (2), Греція (1), Канада (1) }\end{array}$} \\
\hline & \multicolumn{7}{|c|}{ ША (3), Німеччина (2), Франція (2), Ірландія (1) } \\
\hline & \multicolumn{7}{|c|}{$\begin{array}{l}\text { оранія (670), Німеччина (336), США (210), Франція (196), Іт } \\
\text { оролівство (170), Австрія (102), Португалія (82), Греція (50 } \\
\text { 14), Ірландія (41), Люксембург (39), Сінгапур (34), Швейцаґ } \\
\text { 28), Фінляндія (22), Румунія (22), Кіпр (19), Чехія (19), Мал } \\
\text { (7), Угорщина (13), Естонія (12), Віргінські Острови (Брит.) } \\
\text { (0), Мексика (9), Канада (8), Японія (8), Словаччина (8), О } \\
\text { едерація (7), Таїланд (6), Китай (5), Литва (5), Норвегія (5 } \\
\text { ібралтар (4), Корея Півд. (4), Марокко (4), Панама (4), Хор } \\
\text { 3), Словенія (3), ПАР (3), ОАЕ (2), Іран (2), Джерсі (2), Кувє } \\
\text { 2), Латвія (2), Малайзія (2), Саудівська Аравія (2), Сейшел } \\
\text { ), Колумбія (1), Куба (1), Кюрасао (1), Грузія (1), Гернсі (1) } \\
\text { іхтенштейн (1), Макао (1), Тайвань (1), Україна (1); спільн } \\
\text { ранція (3), Австрія (2), Німеччина, Кіпр (2), Іспанія (2), Іта } \\
\text { ), Бельгія (1), Канада (1), Швейцарія (1), Німеччина, Італія }\end{array}$} \\
\hline "hospitality" & \multicolumn{7}{|c|}{$\begin{array}{l}\text { США (14), Німеччина (13), Сполучене Королівство (13), Італія (12), Іспанія (11), } \\
\text { Нідерланди (9), Франція (7), Бельгія (4), Кіпр (3), Греція (3), Гонконг (3), Австрія (2), } \\
\text { Бразилія (2), Хорватія (2), Ірландія (2), Люксембург (2), Віргінські Острови (Брит.) (2), } \\
\text { Андорра (1), ОАЕ (1), Канада (1), Швейцарія (1), Данія (1), Фінляндія (1), Індія (1), Монако } \\
(1), \text { Маврикій (1), Нова Зеландія (1), Катар (1), Таїланд (1), ПАР (1); спільна власність: } \\
\text { Бельгія (2), Німеччина (1), Іспанія (1), СК, Віргінські Острови (Брит.) (1), Італія (1) }\end{array}$} \\
\hline
\end{tabular}




\section{СПИСОК ВИКОРИСТАНИХ ДЖЕРЕЛ:}

1. Мельниченко С., Ведмідь Н., Авдан О. Бренд туристичного підприємства: реєстрація його елементів. Маркетинг як основа формування стратегії соціально-економічного розвитку прикордонного регіону : матеріали Міжнародної науково-практичної конфреренції, (м. Чернівці, Україна - м. Сучава, Румунія, 11-12.11.2020 р.). Чернівці : Технодрук, 2020. С. 18-21.

2. Боєнко О.Ю. Середовище формування бренда через призму економічних, правових та соціально-культурних аспектів. Економіка і організація управління. 2018. № 1(29). С. 43-51.

3. Романюк І.А. Удосконалення управління розвитком суб'єктів сільського зеленого туризму. Л.І. Антошкіна, Н.В. Рунчева, О.Л. Горяча (Ред.). Пріоритетні напрями соціально-економічного розвитку України. Київ : Талком, 2020. С. 124-130.

4. Ілляшенко С.М., Проскурня О.М., Попов М.О. Інтелектуально-інноваційний розвиток туристичних підприємств. Законодавство України у сфрері інтелектуальної власності та його правозастосування: національні, європейські та міжнародні виміри : матеріали 7-ї Всеукраїнської науково-практичної консреренції (м. Kuїв, 27.09.2019 р.). 2019. C. 94-100. URL: http://repository.kpi.kharkov.ua/handle/KhPI-Press/43505

5. EUIPO. URL: https://euipo.europa.eu/ohimportal/en

\section{REFERENCES:}

1. Melnychenko, S., Vedmid, N., \& Avdan, O. (2020) Brend turystychnoho pidpryiemstva: reiestratsiia yoho elementiv [Brand of the tourism enterprise: registration of its elements]. In Proceedings from: Mizhnarodna naukovo-praktychna konferentsiia "Marketynh yak osnova formuvannia stratehii sotsialno-ekonomichnoho rozvytku prykordonnoho rehionu" - International scientific-practical conference "Marketing as a basis for forming a strategy for socio-economic development of the border region" (Chernivtsi, Ukraine - Suchava, Romania, 11-12.11.2020), (pp. 18-21). Chernivtsi: Tekhnodruk. (in Ukrainian)

2. Boienko, O.Y. (2018) Seredovyshche formuvannia brenda cherez pryzmu ekonomichnykh, pravovykh ta sotsialno-kulturnykh aspektiv [Brand environment formation through the prism of economic, legal and socio-cultural aspects]. Ekonomika i orhanizatsiia upravlinnia, 1(29), 43-51. (in Ukrainian)

3. Romaniuk, I.A. (2020) Udoskonalennia upravlinnia rozvytkom subiektiv silskoho zelenoho turyzmu [Improving the development management of the rural green tourism entities]. In L.I. Antoshkina, N.V. Runcheva \& O.L. Horiacha (Eds.), Priorytetni napriamy sotsialno-ekonomichnoho rozvytku Ukrainy - Priority areas of socio-economic development of Ukraine,(pp. 124-130). Kyiv: Talkom. (in Ukrainian)

4. Illiashenko, S.M., Proskurnia, O.M., \& Popov, M.O. (2019) Intelektualno-innovatsiinyi rozvytok turystychnykh pidpryiemstv [Intellectually innovative development of tourist enterprises]. In Proceedings from: 7-ma Vseukrainska naukovo-praktychna konferentsiia "Zakonodavstvo Ukrainy u sferi intelektualnoi vlasnosti ta yoho pravozastosuvannia: natsionalni, yevropeiski ta mizhnarodni vymiry" - 7th All-Ukrainian scientific-practical conference "Legislation of Ukraine in the field of intellectual property and its law enforcement: national, European and international dimensions" (Kyiv, 27.09.2019), (pp. 94-100). Retrieved from: http://repository.kpi.kharkov.ua/handle/KhPI-Press/43505 (in Ukrainian)

5. EUIPO. Retrieved from: https://euipo.europa.eu/ohimportal/en 